\title{
Using Pregabalin as Pre-Emptive Multi-Modal Analgesia for Post- Operative Pain Management: A Randomized Controlled Trial-Case Study
}

\section{Ali Saad*}

Faculty of Medicine, Mansourah University, Egypt

\begin{abstract}
Statement of the problem: A prospective, randomized clinical trial (case study) over 40 patients undergoing surgical procedures.

Methodology and theoretical orientation: To give Pregabalin (Lyrica) $75 \mathrm{mg} 2 \mathrm{~h}$ or more before surgery then $75 \mathrm{mg}$ QHS for 3 days postoperative, to be reassessed by acute pain service team if extension needed. Then add Celecoxib (if not contraindicated) $200-400 \mathrm{mg}$ tablet $1 \mathrm{~h}$ before surgery then $200 \mathrm{mg}$ BID for 3 days only. Ranitidine $150 \mathrm{mg}$ BID could be added. Surgical site-specific regional analgesia whenever possible, PCA morphine can be used if indicated and as a backup plan for breakthrough pain. Then post-operatively, Pregabalin, Celecoxib, Solpadine 2 tablets Q6 h or TID. Findings: 30 patients came calm pre-op., smooth for GA, RA blocks, other 10 patients little anxious. All patients examined second day; 30 patients had smooth sleep, no pain after regional blocks, needed PCA morphine 1-5 mg (10 patients). Other 10 patients continued only on oral tablets.

Conclusion and significance: the new pre-emptive multimodal analgesic combination is safe and effective postoperative. Lyrica regimen may reduce severity of adverse effects of the opioid. Regular review, follow up of patients postoperative by APS team for 4 days is mandatory.
\end{abstract}

Keywords: Pre-emptive analgesia; Pregabalin (Lyrica); Opioids; Celecoxib; Multimodal; Post-operative pain; Acute pain service

\section{Introduction}

Pregabalin sold under the brand name "Lyrica" is used in the treatment of various Neurological disorders like Seizures, Anxiety, Migraine, Central hyperexcitability, etc. Pregabalin is a gammaaminobutyric acid derivative which acts as Ligand for the Voltage gated $\mathrm{Ca}^{2+}$ channels in the Nervous system [1-4]. This action leads to the decrease in the intake of $\mathrm{Ca}^{2+}$ ion through the $\mathrm{Ca}^{2+}$ Channels hence causing depolarization and thus leads to the decrease in the release of Excitatory Neurotransmitters like Dopamine, Adrenaline and Serotonin etc. To reduce the pain in early postoperative period pre-emptive analgesics is more effective than the comparative analgesic treatment during surgery [5]. Preemptive analgesia is defined as a treatment which starts before surgery to prevent the central sensitization formation which comes by the inflammatory injuries during surgery. It is an antinociceptive treatment averts the formation of altered processing of afferent input, which Intensifies postoperative agony. Many New studies on pre-emptive analgesia will be conducted from past several years; among them many are published [6-8].

\section{Objectives}

Preemptive analgesia: Analgesic regimen before the onset of noxious stimuli (commonly before incision).

\section{Goals}

Reduce Central sensitization and Central hyperexcitability of the nervous system, to evaluate the viability of a novel pre-emptive multimodal pain relieving regimen for reducing postoperative torment and complexities.

A prospective, randomized clinical trial case study:

Participants: Patients undergoing surgical procedures (40 Pts).

All patients chosen for Pre-emptive multimodal analgesia treatment group (40 patients) (Figure 1) [9].

\section{Structure}<smiles>CC(C)C[C@H](CN)CC(=O)O</smiles>

- IUPAC name: (S)-3-(aminomethyl)-5-methylhexanoic acid

- Molecular Formulae: $\mathrm{C}_{8} \mathrm{H}_{17} \mathrm{NO}_{2}$

- $\quad$ Molecular Weight: $159.229 \mathrm{~g} / \mathrm{mol}$

- Drug Category: Anti-convulsion drug.

Uses

- $\quad$ Muscle pain treatment

- Seizures

- $\quad$ Anesthesia in most of the surgery.

\section{Mode of Action}

In the voltage-gated calcium channels Pregabalin pre-synaptically binds with alpha-2-delta subunit which is located in the brain and spinal cord. Exact Mode of action is unknown but studies suggest that Pregabalin causes depolarization by inhibiting the Voltage gated

*Corresponding author: Ali Saad, Faculty of Medicine, Mansourah University, Egypt, Tel: 00965-65520979; E-mail: profanesthesia@yahoo.com

Received December 20, 2017; Accepted January 01, 2018; Published January 12,2018

Citation: Saad A (2018) Using Pregabalin as Pre-Emptive Multi-Modal Analgesia for Post-Operative Pain Management: A Randomized Controlled Trial-Case Study. J Formul Sci Bioavailab 2: 119

Copyright: (c) 2018 Saad A. This is an open-access article distributed under the terms of the Creative Commons Attribution License, which permits unrestricted use, distribution, and reproduction in any medium, provided the original author and source are credited. 
Citation: Saad A (2018) Using Pregabalin as Pre-Emptive Multi-Modal Analgesia for Post-Operative Pain Management: A Randomized Controlled Trial-Case Study. J Formul Sci Bioavailab 2: 119.



Figure 1: Group Demographic, outcome comparisons and postoperative follow up of pre-emptive multimodal analgesia comparisons.

\begin{tabular}{|c|c|c|c|}
\hline Demographic & Preemptive multimodal analgesia group $(n=40)$ & Control Group $(n=40)$ & $P$ value \\
\hline Age & $67.9 \pm 7.6$ & $66.3 \pm 10.0$ & 0.147 \\
\hline BMD & $-1.9 \pm 1.3$ & $-2.5 \pm 0.9$ & 0.107 \\
\hline Intraoperative blood loss & $383.0 \pm 89.4$ & $400.3 \pm 84.9$ & 0.379 \\
\hline Postoperative hemovac drain output & $276 \pm 111.1$ & $289.3 \pm 149.1$ & 0.335 \\
\hline Non-union (Cases) & 3 & 4 & 0.692 \\
\hline Post-op. Day & Preemptive Multimodal analgesia group $(n=40)$ & Control group $(n=40)$ & $P$ value \\
\hline Recovery room & $5.90 \pm 1.10$ & $7.12 \pm 1.13$ & 0 \\
\hline After $8 \mathrm{~h}$ & $5.47 \pm 1.17$ & $6.75 \pm 1.12$ & 0 \\
\hline Day 1 & $4.25 \pm 0.89$ & $5.52 \pm 1.06$ & 0 \\
\hline Day 2 & $3.62 \pm 0.92$ & $5.12 \pm 1.13$ & 0 \\
\hline Day 4 & $3.10 \pm 0.92$ & $4.52 \pm 0.96$ & 0 \\
\hline Day 7 & $2.22 \pm 0.69$ & $3.65 \pm 1.29$ & 0 \\
\hline
\end{tabular}

Table 1: Results for Preemptive multimodal analgesia group in patients $(n=40)$.

$\mathrm{Ca}^{2+}$ channels in brain tissue which leads to inhibition of excitatory neurotransmitter like adrenaline, Dopamine etc. $[10,11]$. Some studies also suggest that in mechanism of Pregabalin Noradrenergic and serotonergic pathways are also involved. Meanwhile Pregabalin is an inhibitory neurotransmitter of GABA-Receptor it do not directly bind with GABA, Benzodiazepine or Barbiturate Receptors. 90\% Pregabalin will be excreted in unchanged form through urine because it is a plasma Unbound drug [12-14].

\section{Adverse effect}

$$
\begin{array}{ll}
- & \text {-Nausea } \\
- & \text {-Vomiting } \\
- & \text {-Dry mouth } \\
- & \text {-Blurred vision } \\
- & \text {-Dizziness }
\end{array}
$$

\section{Methodology}

To give Pregabalin (Lyrica) $75 \mathrm{mg} 2 \mathrm{~h}$ or more before surgery then $75 \mathrm{mg}$ QHS for 3 days postoperative to be reassessed by APS team if extension needed, no valium with Lyrica [15]. To add Celecoxib (if not contraindicated) $200-400 \mathrm{mg}$ tablet $1 \mathrm{~h}$ before surgery then $200 \mathrm{mg}$ BID for 3 days only. Ranitidine $150 \mathrm{mg}$ BID could be added [16-18]. Surgical site-specific regional analgesia whenever possible, PCA morphine can be used if indicated and as a backup plan for breakthrough pain. Then post-operatively, Pregabalin, Celecoxib, Solpadine 2 tablets Q6 h or TID [19-22].

\section{Results}

30 patients came calm pre-operative, smooth for GA, RA blocks, other 10 patients little anxious. All patients examined second day; 30 patients had smooth sleep, no pain after regional blocks, needed PCA morphine $1-5 \mathrm{mg}$ (10 patients). Other 10 patients continued only on oral tablets shown in Table 1.

\section{Conclusion}

Pregabalin is most effective anaesthetic drug in the treatment of various pains related to nervous system i.e. Epilepsy, Migraine etc. and may show its effect more efficiently than the high doses of many other anaesthetic drugs. The new Preemptive multimodal analgesic combination is safe and effective postoperative. Lyrica regimen may reduce severity of adverse effects of the opioid. Regular review, follow up of patients postoperative by APS team for 4 days is mandatory.

\section{References}

1. Kissin I (1996) Pre-emptive analgesia. Why its effect is not always obvious Anesthesiology 84: 1015-1019.

2. Crile GW (1913) The kinetic theory of shock and its prevention through anociassociation (Shockless Operation). THE Lancet 182: 16-27.

3. Woolf CJ (1983) Evidence for a central component of post-injury pain hypersensitivity. Nature 308: 686-688. 
Citation: Saad A (2018) Using Pregabalin as Pre-Emptive Multi-Modal Analgesia for Post-Operative Pain Management: A Randomized Controlled Trial-Case Study. J Formul Sci Bioavailab 2: 119.

4. Grass JA (1998) Preemptive analgesia, Problems in Anesthesia, Philadelphia, Liippincott-Raven 10: 107-121.

5. Pasqualucci A (1998) Experimental and clinical studies on preemptive analgesia with local anesthetics. Minerva Anestesiologica 64: 445-457.

6. Hariharan S, Moseley H, Kumar A, Raju S (2009) The effect of preemptive analgesia in postoperative pain relief-a prospective double-blind randomized study. Pain Med 10: 49-53

7. Jadeja C, Khatri H, Oza V (2014) Comparative study of single dose pre-emptive pregabalin vs. Placebo for post-operative pain relief in middle ear surgery. International Journal of Biomedical and Advance Research 5: 3.

8. Pandey CK, Priye S, Singh S, Singh U, Singh RB, et al. (2004) Pre-emptive use of gabapentin significantly decreases postoperative pain and rescues analgesic requirements in laparoscopic cholecystectomy. Can J Anaesth 51: 358-363.

9. Ghai A, Gupta M, Rana N, Wadhera R (2012) The effect of pregabalin and gabapentin on preoperative anxiety and sedation: a double blind study. Anaesth Pain Intensive Care 16: 257-261.

10. Noor M (2007) Pregabalin: Its Pharmacology and Use in Pain Management. Anesth Analg 105: 1805-1815.

11. Kinloch RA, Cox PJ (2005) New targets for neuropathic pain therapeutics. Expert Opin Ther Targets 9: 685-698.

12. Toth $C$ (2014) Pregabalin: latest safety evidence and clinical implications for the management of neuropathic pain. Ther Adv Drug Saf 5: 38-56.

13. Drug Enforcement Administration, Department of Justice. Schedules of controlled substances: placement of Pregabalin into schedule V. Final rule. Fed Regist 70: 43633-43635.
14. Smith K, Roberts M (2007) Sequential medication strategies for post-herpetic neuralgia: A cost-effectiveness analysis. J Pain 8: 396-404

15. Tarride J, Gordon A, Vera-Llonch M, Dukes E, Rousseau CN (2006) Costeffectiveness of pregabalin for the management of neuropathic pain associated with diabetic peripheral neuropathy and postherpetic neuralgia: a Can perspective. Clin Ther 28: 1922-1934.

16. Walia KS, Khan EA, Ko DH, Raza SS, Khan YN (2004) Side effects of antiepileptics. Pain Pract 4: 194-203.

17. Turk DC, Dworkin RH, Allen RR, Bellamy N, Brandenburg N, et al. (2003) Core outcome domains for chronic pain clinical trials: IMMPACT recommendations. Pain 106: 337-345

18. Fassoulaki A, Patris K, Sarantopoulos C, Hogan Q (2002) The analgesic effect of gabapentin and mexiletine after breast surgery for cancer. Anesth Analg 95 985-991.

19. Yokoyama T, Maeda Y, Audette KM, Sluka KA (2007) Pregabalin reduces muscle and cutaneous hyperalgesia in two models of chronic muscle pain in rats. J Pain 8: 422-429.

20. Gilron I (2006) The role of anticonvulsant drugs in postoperative pain management: a bench-to-bedside perspective: [Le role des anticonvulsivants dans le traitement de la douleur postoperatoire: perspective d'une application] Can J Anaesth 53: 562-571.

21. Zesiewicz T, Ward C, Hauser R, Pease Campbell J, Sullivan KN (2007) Pregabalin (Lyrica) in the treatment of essential tremor. Mov Disord 22: 139-141.

22. Vandemergel $X$, Mbeufet $M$, Renneboog B (2006) Intractable hiccups successfully treated with Pregabalin. Eur J of Internal Med 17: 522 